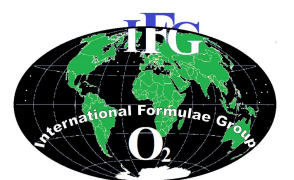

Available online at http://ajol.info/index.php/ijbcs

Int. J. Biol. Chem. Sci. 8(6): 2891-2895, December 2014

International Journal

of Biological and

Chemical Sciences

ISSN 1997-342X (Online), ISSN 1991-8631 (Print)

Short Communication

http://indexmedicus.afro.who.int

\title{
Determination of metals in pepper by flame atomic absorption spectroscopy
}

\author{
Erepamowei YOUNG and Timi TARAWOU* \\ Department of Chemical Sciences, Faculty of Science, Niger Delta University, Wilberforce Island, PMB 71, \\ Yenagoa, Bayelsa State, Nigeria. \\ *Corresponding author; E- mail: ttarawou@gmail.com; Tel.: +234 (0) 8036726459.
}

\begin{abstract}
The health risk of dietary intake of metals by humans cannot be over-emphasized, especially metalcontaminated farm produce from an abandoned waste dump site. Metals could contaminate farm produce during pre- and post-harvest periods. The metal (zinc, copper, chromium, iron, manganese and cobalt) contents of Capsicum annum, Capsicum chinens and Capsicum frutescens pepper samples (harvested from an abandoned waste dump site in Gbarantoru in Bayelsa State) were determined and compared with WHO permissible levels. The pepper samples were crispy-dried, ground to fine powder, and digested with an acid mixture of sulphuric acid, perchloric acid and nitric acid in the ratio of 1:4:40. Prepared samples were analyzed using flame atomic absorption spectrophotometer. The results showed a wide range of concentrations: Capsicum anпиит $(\mathrm{Zn}=40.28 \mathrm{mg} / \mathrm{kg}, \mathrm{Cu}=4.17 \mathrm{mg} / \mathrm{kg}, \mathrm{Cr}=3.32 \mathrm{mg} / \mathrm{kg}, \mathrm{Fe}=105.23 \mathrm{mg} / \mathrm{kg}, \mathrm{Mn}=0.54$ $\mathrm{mg} / \mathrm{kg}, \mathrm{Co}=0.69 \mathrm{mg} / \mathrm{kg})$, capsicum chinens $(\mathrm{Zn}=54.48 \mathrm{mg} / \mathrm{kg}, \mathrm{Cu}=4.22 \mathrm{mg} / \mathrm{kg}, \mathrm{Cr}=2.81 \mathrm{mg} / \mathrm{kg}, \mathrm{Fe}=$ $158.33 \mathrm{mg} / \mathrm{kg}, \mathrm{Mn}=0.66 \mathrm{mg} / \mathrm{kg}, \mathrm{Co}=0.73 \mathrm{mg} / \mathrm{kg})$, Capsicum frutescens $(\mathrm{Zn}=47.45 \mathrm{mg} / \mathrm{kg}, \mathrm{Cu}=4.36$ $\mathrm{mg} / \mathrm{kg}, \mathrm{Cr}=3.20 \mathrm{mg} / \mathrm{kg}, \mathrm{Fe}=63.13 \mathrm{mg} / \mathrm{kg}, \mathrm{Mn}=0.59 \mathrm{mg} / \mathrm{kg}, \mathrm{Co}=0.77 \mathrm{mg} / \mathrm{kg}$ ). The metal concentrations of the three hot pepper samples were found to be below WHO- permissible limits except for zinc in Capsicum chinens, which was found to be higher than the permissible limit. These species of pepper grown in this abandoned waste dumpsite are safe for food as stipulated by WHO.
\end{abstract}

(C) 2014 International Formulae Group. All rights reserved.

Keywords: Metals, pepper, flame, atomic absorption, waste, dumpsite.

\section{INTRODUCTION}

Though, Capsicum (a genus of flowering plants in the nightshade family, Solanaceae) is cultivated worldwide, they are native to the Americans, where they have been cultivated for thousands of years by the people of tropical Americans. A review of the classification of this plant is given by Nwokin et al. (2010). Only three species (Capsicum annum, Capsicum chinens and Capsicum frutescens) will be studied in this research because they are the ones planted, harvested and marketed in the area (Gbarantoru, Bayelsa State, Nigeria) under study.

Generally, Capsicum plants are perennial crop, but they are usually grown as annual crop. It has densely branched stem with an average height of $0.5-1.0$ meters. The species can tolerate most climates, but they are especially productive in warm and dry climates. Growing season is approximately $80-120$ days (Johnson, 2007). It thrives well on moist, well-drained and 
loose-textured soil with a $\mathrm{pH}$ of 4.3 to 9.7 (Johnson, 2007).

Because of the burning sensation caused by capsaicin when it comes in contact with mucous membranes, pepper is commonly used in food products to give them added spice or heat (Stewart et al., 2007).

Farm produce can get contaminated through different anthropogenic sources and many researchers have found different interests in determining metals in farm produce. Antonious et al. (2010) determined the concentrations of heavy metals in plants, fruits and vegetables because of the potential health risks associated with eating heavymetal-contaminated edible plants. Metals could be accumulated in agricultural soils through irrigation and subsequently bioaccumulated in pepper grown in them. In order to investigate the levels of accumulation, Adeyeye (2005) determined trace metals (Zinc, manganese, cobalt, selenium, copper, molybdenum, chromium, iron, aluminium, lead and cadmium) in buds, flowers, fruits, seeds, leaves, stems, roots, cobs, styles, shaft, grains and efflorescence of plants and in soils from Fadama farms in Ekiti State in Nigeria.

Another investigation was also carried out on Fadama Farms (Owodo et al., 2008) on the levels of some trace metals (lead, chromium and copper) in the Fadama soils and pepper (Capsicum annuum) along the bank of River Challawa in Nigeria. Investigations have also been carried out to determine the bioaccumulation of hazardous chemicals in plants, fruits and vegetables (Anhwange et al., 2009; Audu et al., 2005).

An abandoned waste-dump site in Gbarantoru in Bayelsa State (Nigeria) is used for pepper-farming. This farm produce constitute some percent of pepper supply to local markets such as Swali Market in Yenagoa metropolis. The harvested pepper is also exposed to dust during transportation and while on sale in the open baskets and exposed tables in the market. The pepper could be contaminated with metals before harvest (via metal uptake and bioaccumulation) and after harvest. The uptake and bioaccumulation of metals by plant and the factors influencing such phenomena were reported by Yusul and Osibanjo (2006). The possible contamination of farm produce such as vegetables by air and aerosol was investigated and reported by De Nicola et al. (2008). However, the ultimate consequence of the contamination is the attendant health risk; Turkdogan et al. (2003) have reported the health risk of dietary intake of metals by humans and animals. The report established a connection between the prevalence of high gastrointestinal cancer and dietary intake of high levels of metals.

This research was aimed at comparing the levels of $\mathrm{Zn}, \mathrm{Cu}, \mathrm{Cr}, \mathrm{Fe}, \mathrm{Mn}$, and $\mathrm{Co}$ in some species of pepper produced from an abandoned waste dump site with the WHOpermissible metal levels. This was done against the backdrop of the health risk associated with dietary intake of metals.

\section{MATERIALS AND METHODS}

\section{Chemicals/reagents}

Analytical grade chemicals and distilled water were used throughout the study.

\section{Glassware and equipment}

All glassware and plastic containers were washed with detergent, followed by $20 \%$ (v/v) concentrated trioxonitrate (IV) acid, and rinsed with distilled water.

\section{Sample collection and preparation}

The three species of hot pepper (Capsicum annuum, Capsicum chinens, and Capsicum frutescens) were bought at Swali Central Market in Yenagoa, Bayelsa State of Nigeria; all samples were produce from farms in Gbarantoru waste dumpsite.

The pepper samples were washed with tap water, rinsed with distilled water, sliced in nearly uniform size to facilitate drying of the pieces at the same rate. The sliced pieces were then dried in an oven at $105{ }^{\circ} \mathrm{C}$ for 24 hours until they were brittle and crispy. At this stage, no microorganism can grow and care was taken to avoid any source of 
contamination. The dried samples were ground into fine particles using clean mortar and pestle.

\section{Digestion}

The procedure adopted by Awofolu (2005) was used for the digestion of the samples. Oven-dried pepper (Capsicum annuum) was ground into fine powder in a porcelain mortar. $0.5 \mathrm{~g}$ of the ground pepper sample was weighed into $100 \mathrm{~mL}$ beaker followed by the addition of $20 \mathrm{~mL}$ of an acid mixture of sulphuric acid, perchloric acid and nitric acid in the ratio of $1: 4: 40$. This was placed on hot plate (heater) and heated slowly until frosting stopped and the foaming ceased. Then the heat was raised until the mixture started boiling. Boiling was maintained until a clear solution was obtained. The heat was removed; samples were allowed to cool down, filtered and then diluted to mark with distilled water in a $100 \mathrm{~mL}$-capacity volumetric flask. The samples were then analyzed for the concentrations of zinc, copper, chromium, iron, manganese, and cobalt using flame atomic absorption spectrometer (FAAS).

This was repeated for the other species of pepper, Capsicum chinens and Capsicum frutescens. Five replicate analyses were carried out for each of the samples under investigation.

\section{RESULTS}

The concentrations of the selected metals (zinc, copper, chromium, iron, manganese, and cobalt) were determined by flame atomic absorption spectrometer and the results are presented in Table 1. The concentrations of $\mathrm{Zn}, \mathrm{Cu}, \mathrm{Cr}, \mathrm{Fe}, \mathrm{Mn}$, and $\mathrm{Co}$ as given in Table 1 were compared with the maximum permissible standard concentration of the metals as recommended by the World Health Organization (FAO and WHO, 2001); the WHO standards of the metals being studied are presented in Table 2. Calibration graphs were plotted and equations of straight line and regression coefficient $\left(\mathrm{R}^{2}\right)$ values were obtained for all the metals being determined and are presented in Table 3.

Table 1: Concentration of metals in the various hot pepper samples.

\begin{tabular}{lcccccc}
\hline Sample & $\mathbf{Z n}$ & $\mathbf{C u}$ & $\mathbf{C r}$ & $\mathbf{F e}$ & $\mathbf{M n}$ & Co \\
\hline Capsicum annuum & $40.28 \pm 0.03$ & $4.17 \pm 0.03$ & $3.32 \pm 0.03$ & $105.23 \pm 0.09$ & $0.54 \pm 0.02$ & $0.69 \pm 0.01$ \\
Capsicum chinens & $54.48 \pm 0.08$ & $4.22 \pm 0.01$ & $2.81 \pm 0.01$ & $158.33 \pm 0.06$ & $0.66 \pm 0.02$ & $0.73 \pm 0.03$ \\
& & & & & & \\
Capsicum frutescens & $47.45 \pm 0.05$ & $4.36 \pm 0.02$ & $3.20 \pm 0.02$ & $63.13 \pm 0.08$ & $0.59 \pm 0.01$ & $0.77 \pm 0.02$ \\
\hline
\end{tabular}

Table 2: Codex permissible standards for metals in hot pepper (2001).

\begin{tabular}{lc}
\hline Metal & Recommended standard $(\mathbf{m g} / \mathbf{k g})$ \\
\hline $\mathrm{Fe}$ & 300 \\
$\mathrm{Cu}$ & 20 \\
$\mathrm{Cr}$ & 30 \\
$\mathrm{Zn}$ & 50 \\
$\mathrm{Mn}$ & 100 \\
$\mathrm{Co}$ & 50 \\
\hline
\end{tabular}


Table 3: Equation of straight line and regression coefficient $\left(\mathrm{R}^{2}\right)$ values for the metals.

\begin{tabular}{lccc}
\hline Metal & N & Equation & $\mathbf{R}^{2}$ \\
\hline $\mathrm{Fe}$ & 5 & $\mathrm{y}=0.0571 \mathrm{x}+0.0113$ & 0.996 \\
$\mathrm{Cu}$ & 5 & $\mathrm{y}=0.0109 \mathrm{x}+0.0027$ & 1.000 \\
$\mathrm{Cr}$ & 5 & $\mathrm{y}=0.0535 \mathrm{x}+0.0189$ & 0.999 \\
$\mathrm{Zn}$ & 5 & $\mathrm{y}=0.0005 \mathrm{x}+0.0130$ & 1.000 \\
$\mathrm{Mn}$ & 5 & $\mathrm{y}=2.9477 \mathrm{x}+0.0523$ & 1.000 \\
$\mathrm{Co}$ & 5 & $\mathrm{y}=3.992 \mathrm{x}+0.0040$ & 1.000 \\
& & & \\
\hline
\end{tabular}

$\mathrm{N}=$ Number of replicate analysis; $\mathrm{R}^{2}=$ regression coefficient

\section{DISCUSSION}

Comparing the WHO-recommended standards and the determined metal concentrations, it was found that the zinc concentration was tolerable for the hot pepper samples Capsicum annuum $(40.28 \mathrm{mg} / \mathrm{kg})$ and Capsicum frutescens $(47.45 \mathrm{mg} / \mathrm{kg})$. While for the Capsicum chinens sample, the determined zinc concentration was $54.48 \mathrm{mg} / \mathrm{kg}$, which was found to be higher than the permissible limit of $50 \mathrm{mg} / \mathrm{kg}$. Therefore consumption of Capsicum chinens from the same source where the sample was obtained on a continuous basis may be a health risk.

It was further shown in Tables 1 and 2 that for all the pepper samples being studied, the determined concentrations of the other metals $(\mathrm{Cu}, \mathrm{Cr}, \mathrm{Fe}, \mathrm{Mn}$ and $\mathrm{Co})$ were much lower than the permissible recommended levels. Thus, consumption of the three pepper samples would not pose any health risks to consumers. Although the concentrations of iron $(\mathrm{Fe})$ in the three pepper samples were found to be relatively higher than the concentrations of other metals under investigation $(105 \mathrm{mg} / \mathrm{kg}, 158 \mathrm{mg} / \mathrm{kg}$ and 63 $\mathrm{mg} / \mathrm{kg}$ respectively for Capsicum annum, Capsicum chinens and Capsicum frutescens), the values are still within WHO-permissible level, which is $300 \mathrm{mg} / \mathrm{kg}$. The importance of dietary intake of $\mathrm{Fe}$ cannot be overemphasized because it forms part of the structural and functional components of hemoglobin in red blood cells (Alan, 2008), myoglobin in muscles cells (Brunori et al.,
2004) and a constituent of all cysteinato-heme enzymes (Bernard et al., 2004).

Cobalt can be toxic at high levels, however the determined concentration values of cobalt for all the three samples of hot pepper being studied (Capsicum annuит, Capsicum chinens and Capsicum frutescens) were very low $(0.69 \mathrm{mg} / \mathrm{kg}, 0.73 \mathrm{mg} / \mathrm{kg}$ and $0.77 \mathrm{mg} / \mathrm{kg}$ respectively); much lower than the WHO standard of $50 \mathrm{mg} / \mathrm{kg}$.

From Table 2, the high regression coefficient $\left(\mathrm{R}^{2}\right)$ values for $\mathrm{Fe}, 0.996$; $\mathrm{Cu}$, 1.000; Cr, 0.999; Zn, 1.000; Mn, 1.000; and Co, 1.000) showed that the calibration graphs were suitable for verifying unknown metal concentration in the various hot pepper samples.

\section{Conclusion}

All the three samples of hot pepper being studied contained various concentrations of zinc, copper, chromium, iron, manganese, and cobalt. The metal concentrations of the three hot pepper samples were found to be within tolerable limits except for zinc in Capsicum chinens, which was found to be higher than the permissible limit of $50 \mathrm{mg} / \mathrm{kg}$. The concentration of iron $(\mathrm{Fe})$ in the three pepper samples were found to be relatively high and was desirable since the permissible standard recommended for iron is $300 \mathrm{mg} / \mathrm{kg}$. Therefore, farm produce (sold in Swali local market) from abandoned wastedump site at Gbarantoru in Bayelsa State (Nigeria) is safe for consumption in respect of 
the metals under investigation as stipulated by WHO.

\section{ACKNOLEGDEMENTS}

The authors gratefully acknowledge the kind permission of the Department of Chemical Sciences, Niger Delta University, Wilberforce Island, Yenagoa, for the use of reagents and Facilities in their Laboratory.

\section{REFERENCES}

Adeyeye EI. 2005. Trace metals in soils and plants from Fadama farms in Ekiti State, Nigeria. Bull. Chem. Soc. Ethiopia, 19: 23-34.

Alan NS. 2008. Hemoglobin Research and the Origins of molecular medicine. Blood, 112(10): 3927-3938.

Antonious G, Snyder J, Burke T, Jarret R. 2010. Screening Capsicum chinens fruits for heavy metals bioaccumulation. $J$. Env. Sci. Health, 45: 562-571.

Anhwange BA, Kagbu JA, Agbaji EB, Gimba CE. 2009. Trace metal contents of some common vegetables from an irrigated farm along the banks of River Benue within Makurdi metropolis. EJEAFChe, 8: $1150-1155$.

Audu AA, Lawal AO. 2005. Variation in metal contents of plants in vegetable garden sites in Kano metropolis. J. Appl. Sci Environ. Manage, 10: 105-109.

Awofolu OR. 2005. A survey of trace metals in vegetation, soil and lower animals along some selected major roads in metropolitan city of Lagos.
Environmental monitoring and Assessment, 105: 431 - 447.

Bernard M, Samuël P, de Visser, Sason Shaik. 2004. Mechanism of oxidation reactions catalyzed by cytochrome P450 enzymes. Chem Rev., 104: 3947 - 3980.

Brunori M, Bourgeois D, Vallone B. 2004. The structural dynamics of myoglobin, JSB., 147(3): $223-234$.

FAO, WHO. 2001. Food additives and contaminants. Joint FAO/WHO Food Standards Programme, ALINORM 01/12A: $1-28$.

Johnson W. 2007. Final report on the safety assessment of Capsicum annuum extract, Capsicum annuum fruit extract, Capsicum annuum resin, Capsicum annuum fruit powder, capsicum frutescens fruit, Capsicum frutescens fruit extract, Capsicum frutescens resin, and capsaicin. Int. J. Toxicol., 26: 3-10.

Nwokem CO, Agbaji EB, Kagbu JA, Ekanem EJ. 2010. Determination of capsaicin content and pengency level of five different pepper grown in Nigeri. NY Sci. J., 3(9): 17-21.

Owodo UA, Uzairu A, Balarabe ML, Okunola OJ, Adewusi SG. 2008. Levels of some trace metals in the Fadama soils and pepper (Capsicum annuum) along the Bank of River Challawa, Nigeria. Asian J. Sci. Res., 1: 458- 463.

Stewart JC, Mazourek M, Stellari GM, O’Connell M, Jahn M. 2007. Genetic control of pungency in C. chinens via the Pun 1 locus. J. Exp. Bot., 58: 979 - 983. 